\title{
COMMUNICATIVE STRATEGIES IN MASS MEDIA: THE IMAGE OF RUSSIA IN MODERN SPAIN
}

\begin{abstract}
The article is devoted to the current issues related to the media and the challenges journalists working in this field facing are facing. It is about understanding the concept of "image" of the country which has two meanings, as well as the importance of creating a positive vision of a state by the world community. The complexity of the processes of mutual understanding impacts negatively on building a constructive dialogue at the interstate level, which in turn leads to the creation of tension and aggravation in international relations. The author pays attention to the exceptional importance of the formation of a positive image of the state, because it ultimately has a special impact on the internal and external factors of its development. The problem is considered on the example of Russia and Spain, paying special attention to their perception reflected in the media of each other. The article contains the data of research on the subject of publications about our country and their positioning in the print media of Spain, as well as the important role which the headlines play actively affecting the collective consciousness of society. The article emphasizes the difference between the image of Russia as a country and the image of its people, as well as the influence of stereotypes that continue to impact on the creation of the image of States. In conclusion, summarizing the findings of the research, the author notes the need to actively develop and deepen Russian-Spanish relations in the field of culture and education, which will have a positive impact on the development of Russian-Spanish relations in general.
\end{abstract}

Key words: communication, mass media, communicative strategies, image of countries, international relations, interstate relations, Russia-Spain, discourse, stereotypes, collective consciousness, fake news, international community.

\section{Author}

\section{Pirozhenko Olga Viktorovna}

Ph. D. (the University of Valencia (Spain),

Director of the Russian-Spanish Centre of Education and Cooperation of the Institute of State Service and Administration of Russian Presidential Academy of National Economy and Public Administration (Moscow, Russia)

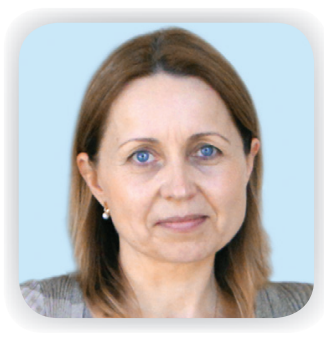

ommunicative strategies are the part of the communicative impact aimed at achieving a certain communicative goal.

We can talk about models or formulas such as:

- presentation or passive communication;

- manipulation or active communication;

- convention or interactive communication.

The second type of communication strategies is manipulation which is usually supported by complex efforts and can be transformed at any time in whole or in part, in accordance with the qualitative changes that characterize the present.

When we talk about communication strategies and tactics, we mean the choice of specific techniques urged to achieve a certain success. We are talking about a number of verbal and non-verbal means, the use of which allows you to achieve your goals. For example, to influence the reader, listener or viewer.

There are a lot of communicative strategies. One of them is discursive.

The world media choose certain communicative strategies based on philoso- 
phies and ideas that can be very different. One of the main is the formation of mass consciousness, reflecting the spiritual values of the general population, its traditions, tastes and needs. These factors are the basis for the creation of positive or negative images of countries, nations and peoples.

In international communication the concept of " image of the country" has a strong place. We are talking about the emotional perception of a state, which seriously affects its ability to attract or repel tourist flows, conduct active trade, position itself in the international arena, etc. When we analyze the image of a country, it becomes clear that it is based primarily on national images and symbols that characterize it. As a rule, they are related to the geographical location of a state, historical, cultural and religious traditions and customs of its people, etc.

The need to create a positive image of a state is absolutely obvious and undeniable. This topic is particularly relevant in these days when the role of mutual understanding is a key factor providing unique opportunities for overcoming the difficulties associated with dead-end situations that arise at different stages and levels of communication processes, of both bilateral and multilateral nature.

The prestige of the country in the international arena has a very positive impact on the national-patriotic sentiments of its own people, and its attractive image helps to strengthen its position in the political arena, contributes to the strengthening of bilateral relations, improves goodneighbourly relations.

The media play a special and very important role in shaping the image of a country. They are not only one of the main sources of information, but also exercise real control over public opinion, affecting the collective consciousness. As Jim Morrison" said "Those who

1 James Douglas Morrison is an American singer, poet, leader and vocalist of "the Doors". control the media have control over the minds". 2

Most of the country's image/brand studies are interdisciplinary. Today their popularity is quite high, and the origins lie in the personal image, which actually goes into the country image, as well as in political marketing.

Despite the fact that "image and brand" are the different concepts, sometimes they are used interchangeably.

However, the "image" is usually associated with existing ideas in philosophical and cultural aspects, the "brand" is used in utilitarian and practical terms, and the "image" is a cross between the image and the brand, it is created and transformed based on the objectives.

There are two meanings of the concept of image. The first means the most capacious concept of the general character, the second is connected with representation of the image which is influenced to change it. The brand is a set of positive characteristics that allows to position the country favorably in terms of attracting investments, promoting national brands, developing tourism, etc. Today, many countries of the world are actively promoting the best of what they can offer to the world community, thus strengthening the position of the state in the interstate relations and international relations in general. A remarkable example of this is the project "Marca España" which involves both official structures and representatives of the business and public circles of Spain. The success of this initiative is undeniable, because today the results of the project have exceeded all expectations and have achieved a successful implementation of such initiatives.

An interesting fact is that according to the research conducted by the Royal Spanish Institute Elcano ${ }^{3}$ Russia is a country where Spain is perceived as the most

\footnotetext{
2 «Quien controla los medios de comunicación, controla las mentes» (James Morrison) https:// es.wikiquote.org/wiki/Jim_Morrison

${ }^{3}$ CM.: http://www.realinstitutoelcano.org/
} 
positive and highly appreciated by respondents. Unfortunately the image of Russia in Spain is not so positive. This, in turn, affects many processes connected with the development of bilateral relations and requires some attention to this topic on the part of Russia.

Dutch linguist Teun van Dijk (niderl. Teun Adrianus Van Dijk) is one of the founders of the theory of text and speech acts. He devoted his research to the analysis of discourse most of which became classics in this scientific field.

A well-known linguist drew attention to the fact that directing the collective consciousness the media actively influence it, experiencing, in turn, the mutual influence of society on the communicative strategies used by the media.

According to Theun van Dyck "...our knowledge of the world is based on a wealth of information that we read or hear daily.." [4. - P. 29-30].

At the time it was the specialists of marketing strategies that drew attention to the trend linking the success of a state with its image existing in the collective consciousness of the world community. Thus in the field of view of professionals there was an understanding of the need to create a correct image of the country, helping to promote it in different directions. In this regard we can remember the statement of a wellknown expert in the field of marketing strategies F. Kotler who argued that: "...the reputation of the country largely depends on its perception of the world community including ideas, impressions, beliefs and legends that exist about this country..." [1. - P. 16 ].

The media is a kind of barometer that transmits the direction of movement of trends that reflect the image of the world. It is curious that, as a rule, the portrait of one country is created not by itself and its people, but by other countries of the world community. In this regard we can remember the Spanish phrase "Los pueblos nunca se miran en los espejos" ("people never look at themselves in the mirror") ${ }^{1}$. An interesting fact is the observation that the people of a single country can afford to be quite skeptical and sometimes critical in some of their characteristics expressing their own opinion on this matter. When such opinions are heard in the mouths of other peoples, it can cause quite negative reactions.

Studies related to the vision of Russia were conducted with the faculty of Philology, Translation and Communication of the University of Valencia [3]. They included the analysis of information published about Russia in one of the leading publications of the Spanish autonomy of the Valencian Community. I mean the newspaper "Las Provincias" in the period from 2006 to 2014. Visual images accompanying the texts of articles on Russian reality in the period from 2006 to 2015 were also analyzed. In total we are talking about 4387 articles and 1742 titles in which the main actor is Russia.

In general according to statistics Russia is mentioned in the Spanish media 2.6 times more often than Spain in the Russian media [3]. Linguistic analysis of the discourse of the Spanish media associated with Russia demonstrates its active and independent position on the world stage, the ability to make important decisions and be responsible for them while using methods leading to the creation of the image of the state practicing in the international arena the imposition of opinions and actions from the position of force, characterized by unpredictability of behavior and certain aggression.

The theme prevailing in the semantics of the titles of publications about Russia is the military theme, as well as the internal life of the country. At the same time close attention is paid to the actions of the authorities and especially to the personality of the Russian President. There is an attempt to use the mechanism of

${ }^{1}$ Carlos Ruíz Zafón. La sombra del viento. Planeta, 2010. 
influence of sensations and fakes leaving out of sight the wealth of Russian culture, the real achievements of Russian society, the political and personal qualities of the President of the Russian Federation. As a result a certain picture is created, which is reflected in the collective consciousness of Spanish society. The image of today's Russia is based on it.

The presence of our country is significant in the sections devoted to international topics, as well as in publications on sports topics (2065 articles and 698 articles). In the texts of headlines Russia appears in the proportion of $28 \%$ of $100 \%$ (sports, political and economic topics), the presence on the front pages of publications is not significant: $3 \%$ of $100 \%$ [3].

In light of the emotional tone and news coverage $47 \%$ of the headlines are negative, $23 \%$ are positive and $30 \%$ are neutral. [3]

Historically a number of stereotypes about Russia continue to exist, having a serious impact on its image. There is an understanding that over time and certain trends of modernity stereotypes have qualitative and quantitative changes. Today, however, it continues to be the classic "cold" and "vodka". The subject of crime and espionage is no longer as important as it was before which is undoubtedly a very encouraging fact. However, the image of insecure and unsafe country that has developed after the tumultuous years of "perestroika" still prevails in the collective consciousness of the Spanish society.

One of the most interesting conclusions of the research is the fact that despite the more negative image of Russia created by the media, the attitude towards Russians remains positive in Spain without being directly affected by communication strategies and trends.

Russia and Spain are very different for obvious logical reasons due to geographical, cultural and historical differences. Nevertheless both countries have a huge mutual interest and a pronounced sympathy for each other. "Being two opposite ends of the European axis" (..siendo los dos polos del gran eje europeo..), in the words of the Spanish philosopher Jose Ortega y Gasset [2], we move towards each other, because as we know opposites are attracted (in the Spanish version: "Los extremos se tocan").

In this regard it is impossible not to recall the presence of certain historical parallelisms between Russia and Spain, acts of deep positive emotions and feelings, for example, "children of war" ("niños de la guerra") lovingly adopted in the USSR, and the children of Chernobyl to which Spanish families treated as their own. The importance of human contacts are good as well as the positive influence of the richest cultures and the desire to get to know each other is great.

The expansion and strengthening of ties in the field of education, culture and sports between Russia and Spain is an important factor that is fundamental for the deepening of bilateral relations in other areas. It is the source of qualitatively positive trends that make up the platform for effective intercultural dialogue.

\section{References}

1. Kotler Ph., Bowen J., Makens J. Marketing para turismo. trad. Madrid: Pearson Prentice Hall, 2003.

2. Ortega y Gasset J. La España invertebrada. Barcelona: S.L.U Espasa Libros, 2011.

3. Pirozhenko O. La imagen de Rusia en la prensa valenciana. 2015. URL: http://roderic.uv.es/ handle/10550/50893 (accessed 17.02.2019).

4. Teun A. van Dijk. Racismo y análisis crítico de los medios. Barcelona: Paidos, 1997.

5. Evgenieva T.V. Psihologiya massovoi politicheskoi kommunikacii [Psychology of mass political communication]. Moscow, Jurait Publ., 2018. 299 p. 
6. Volodenkov S.V. Internet-kommunikacii v global'nom prostranstve sovremennogo politicheskogo upravleniya [Internet communications in the global space of modern political governance]. Moscow, Moscow University Press, 2015. 269 p.

7. Rakityansky N.M. Politicheskaya psihologiya. Psihologicheskoe portretirovanie [Political psychology. Psychological portraiture]. Moscow, Jurait Publ., 2018. 187 p.

\section{Article translated from Russian into English by Anastasia Matusova}

